\title{
Serving the Survivors of Human Rights Abuses: Canadian Centre for International Justice (CCIJ)
}

Caitlin Hawkes-Frost and Rochelle Stevenson

$\mathrm{T}$ he Canadian Centre for International Justice (CCIJ) is a national, nonprofit, non-governmental organization based in Ottawa, Ontario that provides legal information and support services to survivors and relatives of victims of severe human rights abuses. Composed of experts in human rights, law, immigration and health services, the CCIJ's mission is to seek justice and healing for those who have experienced genocide, torture or other human rights violations. In a world marked by ongoing atrocities and brutal human rights violations, the CCIJ provides a range of muchneeded services to individuals with cases connected to Canada.

Primarily a social justice organization, the CCIJ offers a variety of resources and referral services, both for survivors and for individuals with close relations to victims of human rights abuses. The CCIJ is limited to addressing what are generally considered the most severe violations: acts of torture, murder and forced disappearances by governments or state officials, as well as broader abuses, including crimes against humanity, war crimes and genocide. This narrow list of violations includes those that are subject to universal jurisdiction, meaning that these abuses can be investigated and prosecuted anywhere in the world, regardless of where the violations occurred or the nationality of the victim and perpetrator.

The CCIJ will conduct investigations into human rights abuses on behalf of victims, and then provide the necessary information and referrals for those individuals to pursue their own chosen course of justice and to hold their abusers accountable for violations and atrocities. Investigations may result in prosecutions, extradition proceedings or civil lawsuits where survivors may seek financial compensation from the perpetrator. While the CCIJ does not provide legal representation, it does remain involved, providing assistance to the survivors in the process of justice-seeking. This includes helping the survivors retain legal counsel and obtain access to victim support funds.

In order for the CCIJ to become involved, the case must have some connection to Canada, often through the presence of a survivor or relative or the perpetrator. These criteria narrow the investigative capacity of the CCIJ, but do not impact its ability to seek compensation for survivors or for the CCIJ to engage in publicity campaigns to raise the profile of the abuses of human rights in Canadian society. When it comes to supporting the survivors of human rights abuses, the CCIJ itself does not provide professional emotional support services for torture survivors, but 
is connected to and makes referrals to a range of organizations, such as the Canadian Centre for Victims of Torture. Instead, the CCIJ supports survivors by investigating abuses and through legal reform efforts to help facilitate formal avenues of justice for human rights abuses such as genocide and torture. One example of this work is the CCIJ's efforts to reform the State Immunity Act in Canada, a piece of legislation that essentially provides foreign governments with immunity from being sued in Canadian courts. While individuals can be prosecuted anywhere under the principle of universal jurisdiction, governments frequently have immunity from civil lawsuits. The CCIJ is pressuring for changes to the State Immunity Act, not only in light of ongoing abuses, but also because of the limited resources of the Canadian government to pursue prosecutions.

Although the CCIJ provides essential support to survivors of human rights violations, due to limited resources and the constraints of universal jurisdiction, the organization can only pursue a relatively small range of abuses. Nevertheless, if contacted by a survivor of other human rights violations, the CCIJ tries to provide referrals to other organizations. Even with the challenges faced by the CCIJ in trying to achieve justice, they offer valuable support to survivors of human rights violations. The support and information, the connection to other support groups, the investigations and resulting evidence provided for prosecutions or civil cases, and the law reform efforts to improve legal mechanisms are all vital to facilitating the form of justice that survivors choose to pursue. The CCIJ provides ready access to much needed legal resources for survivors who have fled their homes and arrived in an unfamiliar environment, following their experiences of violence and brutality. Since the CCIJ is a non-governmental and non-police organization, many survivors are more trusting of the help offered and this trust is an important step in the healing and justice-seeking process.

\section{CONTACT INFORMATION}

Canadian Centre for International Justice

312 Laurier Avenue East Ottawa, Ontario, Canada K1N 1H9 Phone: (613) 744-7667 Fax: (613) 746-2411 Email: info@ccij.ca Website: www.ccij.ca 


\begin{abstract}
About the Authors
Caitlin Hawkes-Frost is a Master's student in the Department of Criminology at the University of Ottawa. Caitlin's primary research interests include restorative and transitional justice, women's and sex worker's rights, experiences of imprisonment and critical criminology.

Rochelle Stevenson is a Master's student in the Department of Criminology at the University of Ottawa. Her primary research interests are violence against women, animal cruelty, media and crime, research methods and criminological theory. She has extensive volunteer and research experience working with and supporting federal prisoners in British Columbia.
\end{abstract}

Both authors conducted research on the CCIJ in a graduate course in Criminology on human rights and crimes against humanity at the University of Ottawa. 